\title{
Believable Witnesses
}

John J. Frey III, MD*

(Fam Med. 2019;51(7):549-51.)

doi: 10.22454/FamMed.2019.851595

$\mathbf{0}$ ver the past few decades, I have been reading through large numbers of general practitioner (GP) autobiographies. They chronicle the stories of training, finding a practice, and struggling with the challenges of doing right by their patients and communities in an environment that relentlessly threw up obstacles to getting patients what they needed. Unfailingly, these books tell stories of patients who the authors have found to be difficult, joyful, humbling, and a source of larger truths about practice. I have felt a strong sense of common purpose and hope from these doctors from the middle of the last century.

David Loxterkamp, MD, has written two books about his life and practice over a 35year career that include deeply personal reflections of the struggles and satisfaction that accompany the work and disquisitions on his own family of origin, on the life and work of Ernest Ceriani, MD, of Kremmling Colorado and of the writing of John Berger about the life of Dr John Eskell, a GP practicing in the forest towns on the border of Wales. ${ }^{1-3}$ As importantly, Loxterkamp has been a serial essayist for decades. His brilliantly written stories about his patients and what he has learned from them are perhaps the best description of how a doctor can find what Parker Palmer called true community: "one that supports rather than supplants the individual search for integrity." A longtime custom in Northern New Mexico is to place decorated crosses or other memorials as reminders of people who have died on highways and footpaths. The term for them is descanso, which can be translated as "rest" or "breathing space," and can also be interpreted as calls to reflection and memory. Many of us over the past 3 decades have seen Loxterkamp's essays as descansos on our own journeys. Younger doctors can use them as guides to their struggles yet to come.

Now, as he retires from clinical practice with all the emotions that that engenders ${ }^{5}$ and moves to a career as a part-time residency teacher, we benefit from Loxterkamp's observations about education as well. This issue of Family Medicine relays the first reactions of this thoughtful colleague who has served as a career exemplar of the therapeutic relationships that have always been at the core of the discipline. ${ }^{6}$ Having Dr Loxterkamp look at residency education from the inside feels a bit like having a longtime friend drop in to visit when we haven't had the chance to pick up the house. He knows to some extent what he is going to find, but the messes we have created may be embarrassing to us.

Despite the changes in medical practice and structure during his practicing career, and the changing relationship between and among physicians, Loxterkamp's observation that the structure of residency education has not changed much since he began 40 years ago should not be taken as a compliment. And he is not alone in that regard. The recommendation to change education to reflect modern patient and community realities has been a conclusion of almost every examination of residency education for decades. ${ }^{7-9}$ Yet, one could argue, little has changed except around the edges. Residency programs persist with hospital and subspecialty rotations and sacrifice continuity and opportunities to engage with communities, schools, and workplaces in meaningful ways even though educators know

${ }^{*}$ Emeritus editor of Family Medicine. 
that those experiences are among the most important in understanding the fundamental work of primary care. Loxterkamp writes "I believe that family doctors will always be generalist-trained, relationship-centered, and community-oriented." How well those values are represented in residency education should be the measure of quality, not solely the quantification of training.

Robert Pirsig used the term "gumption traps" to define obstacles that keep us from moving forward. He described value traps-internal traps that block cognitive understanding-as the most difficult gumption traps to overcome. ${ }^{10} \mathrm{~A}$ value trap is "an inability to revalue what one sees because of commitment to previous values...you must rediscover what you do as you go. Rigid values make this impossible." Education almost always suffers from a stuckness, an "orthodoxy of belief" that Gayle Stephens lamented early in the family medicine movement. ${ }^{11}$ This stuckness may also reflect an existential fear that too much change leads to perdition.

Loxterkamp's perspective is that of a longtime practitioner of the values he espouses, not in the hothouse environment of academic family medicine, but in the unpredictable lived life of community. He is what Robert Coles called a "believable witness," whose voice carries the power of experience and can speak credibly to the changes in a physician's life over time. ${ }^{12}$ Young family physicians want to make a difference and they need to learn about that as part of their training from people like David Loxterkamp and the other believable witnesses in every community, not assume they will learn it once they begin practice. Residency education is learning on a very steep curve. But having witnesses along the way who coax residents back to values and beliefs of service, relationships, and comfort with uncertainty can help make the curve seem less like a mountain.

Loxterkamp poses the question "have [residents] learned what it means to be a family doctor?" To answer that question, he suggests

... programs and their training practices have an obligation to preserve their distinct culture. To do so, they must have control over the budget, hiring practices, curriculum development, program mission, and social identity.

Autonomy is essential because communities are particular. Echoing Pirsig, the Willard report, which established a blueprint for residency education in 1966, emphasizes "the necessity for flexibility in programs if they are to meet the needs of society. Rigid standardization should be avoided."13

Loxterkamp describes the changing culture of the small town in Iowa where he was born and its need to rethink structure while retaining its core constituencies of family and community linked to enduring values. Thus, managing populations, even with new tools, does not function optimally in the current structure of residency education. ${ }^{14}$ Finding ways of caring for difficult and challenging patients over many years, such as the one he calls Britini in his essay, while not losing hope, as well as finding ways to navigate personal, professional, and community boundaries are tasks that demand emotional resilience, strength, and a belief that the efforts are worthwhile. They also demand more time and engagement in the community and the practice than is currently present in today's highly regulated environment of residency education. John Saultz framed it as education suffering from a shortage of architect/leaders to focus on builder/managers. Without a new vision, imagination is unlikely to emerge from old blueprints. ${ }^{15}$

One of my teachers told me a story about his wife skiing, continuously falling, getting back on her skis, and then falling again. Seeing her growing frustration, an older man skied over to her after she had fallen again and told her that she had to change her perspective. $\mathrm{He}$ said, "to keep from falling, young woman, you have to gather your courage, and lean out over the hill." It seemed counterintuitive to her, but it worked.

Perhaps it is time for residency education in family medicine to lean out over the hill. It might even be time to start all over again. Melding creativity and innovation with values is where family medicine came from and has to be the strategy for where it goes. The challenge for the discipline will be to change dramatically while retaining what got it to this point in the first place. Seeking out encouraging and supportive teachers like David Loxterkamp - the elders who were once the first residents to take a chance on a new idea-will assure a rich conversation about the future. There will also be new doctors who will find their way, with courage, with tenacity, with innovation, and with humility, and make a difference. They are the new voices. Ask them in.

CORRESPONDENCE: Address correspondence to Dr John Frey III, 8 Avenida La Scala, Santa Fe, NM, 87506. 608217-2968. john.frey@fammed.wisc.edu. 


\section{References}

1. Loxterkamp D. What Matters in Medicine: Lessons from a Life in Primary Care. Ann Arbor, Michigan: University of Michigan Press; 2013.

2. Loxterkamp D. A Measure of My Days: The Journal of a Country Doctor. Hanover, NH: University Press of New England; 1997.

3. Berger J, Mohr J. A Fortunate Man: The Story of a Country Doctor. New York: Vintage Books; 1967.

4. Palmer P. A Hidden Wholeness: The Journey Toward an Undivided Life. San Francisco: Josey Bass; 2004.

5. Loxterkamp D. When it's time to retire: notes from the afterlife. Ann Fam Med. 2018;16(2):171-174.

6. Loxterkamp D. Whither family medicine? Our past, future, and enduring scope of practice. Fam Med. 2019;51(7):555558.

7. Hughes LS, Tuggy M, Pugno PA, et al. Transforming training to build the family physician workforce our country needs. Fam Med. 2015;47(8):620-627.

8. Carney PA, Eiff MP, Green LA, et al. Transforming primary care residency training: a collaborative faculty development initiative among family medicine, internal medicine, and pediatric residencies. Acad Med. 2015;90(8):1054-1060.
9. Merenstein JH, Schulte JJ. A residency curriculum for the future. The STFM Task Force on Residency Curriculum for the Future. Fam Med. 1990;22(6):467-473.

10. Pirsig RM. Zen and the Art of Motorcycle Maintenance: An Inquiry Into Values. New York: Harper Collins/Harper Torch; 2006.

11. Stephens GG. Family medicine as counterculture. Fam Med. 1998;30(9):629-636.

12. Coles $\mathrm{R}$. The humanities in postgraduate training. JAMA 1987;257(12):1644.

13. Willard W. Meeting the Challenge of Family Practice: The report of the ad hoc committee on education for family practice of the council on medical education of the American Medical Association. Chicago, Illinois: American Medical Association; 1966.

14. Hollander-Rodriguez J, DeVoe JE. Family medicine's task in population health: defining it and owning it. Fam Med. 2018;50(9):659-661.

15. Saultz JW. Revolutionary leadership and family medicine education. Fam Med. 2008;40(4):277-280.

\section{Innovative Efforts Toward High Performing Academic Family Medicine Practices Call for Papers for a Special Issue}

Family Medicine requests submissions of original papers describing innovations that have improved one or more aspects of academic family medicine practice.

Submitted papers can address efforts to either optimize the patient and/or clinician experience within the practice or to improve the practice's outreach and community impact. Submissions may be original articles, brief reports, or narrative essays. Our goal for this special issue is to publish manuscripts with robust descriptions of the intervention and the criteria by which they have been evaluated. Narrative essays should relate stories about the experiences of faculty, staff, or students working in such settings. All papers must include objective evaluation data to support the value of the innovation, ideally over multiple years.

Submission Deadline: July 31, 2019.

All submissions should comply with the journal's instructions for authors: https://journals.stfm.org/ familymedicine/authors/. While our standard word limits apply to these submissions, articles may include appendices to allow more detailed descriptions of practice innovations. 